\title{
Vyłváření etnokulturních minoritních identit a jejich sociální inkluze
}

\author{
Csaba Szaló - Eleonóra Hamar
}

„Česká společnost“, či přesněji řečeno společnost lokalizovaná na teritoriu v současnosti ovládaném českým státem, je ve své podstatě multietnická, multináboženská a mnohojazyčná. ${ }^{1}$ Nepřispěly $\mathrm{k}$ tomu (pouze) současné sociální procesy, jako je globalizace a nadnárodní migrace, ale z historického hlediska se jedná rovněž o výsledek etnokulturní skladby místních obyvatel českých měst a vesnic, která vždy bývala rozmanitá, navzdory mnoha národnostním hnutím a dramatickým změnám v minulém století. Př́íladem může být fakt, že přestože významná část místní židovské a romské populace byla za druhé světové války přinucena k odchodu nebo byla zlikvidována nacistickým režimem a přestože většina německých obyvatel byla z teritoria nově vzniklého Československa vzápětí po válce odsunuta, česká společnost svůj multietnický charakter úplně neztratila.

V současné české společnosti existuje řada diskurzů a institucí, které si nárokují reprezentaci různých etnokulturních kolektivit. Oficiální vládní statistiky (tj. Sčítání lidu) zdůrazňují velký počet obyvatel jiné než české národnosti žijících v České republice. O jeho významu svědčí též skutečnost, že byla ustavena Rada vlády pro národnostní menšiny, která se má zabývat otázkami etnokulturních menšinových skupin v české společnosti. Existují různá občanská sdružení, která pěstují a uchovávají etnokulturní identitu svých členů - např́íklad mad'arské a bulharské kluby. ${ }^{2}$ Vychází také celá řada cizojazyčných časopisů a novin, např́íklad slovenské Listy nebo ruská Russkaja Čechija. ${ }^{3}$ Jsou zde obchody s knihami, hudbou a potravinami, jako je Ruský salón v Praze a vietnamské etnické trhy pro zákazníky daných etnokulturních identit. Nakonec můžeme zmínit specifické etno-ekonomické instituce, jako jsou malé arabské směnárny, vietnamská a čínská bistra s pivem a nudlemi a sítě takzvaných „klientů“ koordinující tisíce pololegálních ukrajinských stavebních dělníků.

Výše zmíněné diskurzy a instituce nepoukazují pouze na existenci různých etnických kolektivit, ale zároveň vytvářejí etnokulturní identitu osob, které je využívají. V tomto textu vycházíme právě z této perspektivy a sledujeme vytváření kulturních identit minoritních skupin v etnicky různorodém sociálním prostoru České republiky. Spíše než na demografickou deskripci etnicky definovaných skupin a populací se zaměříme na mapování role, kterou tyto instituce a diskurzy hrají v procesech formování etnokulturní identity (Brubaker 1996). ${ }^{4}$ V centru naší pozornosti stojí praktické vytváření smyslu pro etnicitu coby zásadního prvku etnokulturních identit.

V tomto textu uživáme termín ,etnokulturní identita“ jako analytickou kategorii (Brubaker 1992). Pomocí této kategorie se snažíme porozumět tomu, jak jsou identity formovány institucemi a diskurzy, které zastupují etnické skupiny, menšiny a národy. Etnokulturní identity - podobně jako identity náboženské a sub-kulturní - mohou být definovány jako specifické formy soci- 
álních identit, které typifikují osoby jako prvky specifických kolektivit (Schutz a Luckmann 1973, Berger a Luckmann 1967). V důsledku toho pojímáme výrazy jako „etnická skupina“, „menšina“ a „národ“ jako typifikační praktické kategorie. Ze sociologického hlediska nejsou tyto praktické kategorie reprezentující diference a distinkce přijatelné jako interpretační, analytické kategorie pro sociologické porozumění (Bourdieu 1992a, 1992b). Jelikož jsou obvykle kodifikovány v politických a veřejných diskurzech a také ve zdravém rozumu, měly by být chápány spíše jako znaky mocenských vztahů než jako adekvátní deskripce sociální reality.

\section{Ełnické pole: taxonomické diference a hierarchické distinkce}

Institucionální a diskurzivní mechanismus vytváření identity se projevuje v konkrétních sociálních událostech. I když se zdá, že procesy formování etnokulturní identity jsou obvykle spojovány především se sociálními událostmi menšin, upozorňujeme, že diskurzivní utváření menšinových etnokulturních identit je neoddělitelně spojeno s dominantními etnokulturními identitami. Kromě toho způsob, jakým jsou minoritní etnokulturní identity konstruovány v hegemonních diskurzech, má často nerozpoznaný vliv na dominantní etnokulturní identity. Diskurzy totiž ustavují taxonomické diference a hierarchické distinkce, jejichž symbolické důsledky nemohou být omezeny pouze na identity menšinové.

Kulturní festival „Multikulturní Brno“, který v letech 2001-2003 organizovalo občanské sdružení Mládež pro interkulturní porozumění (MIP) v Brně, slouží jako vhodný př́iklad sociální události, v níž se odhalují diskurzivní mechanismy vytváření kulturní identity. Pro vysvětlení těchto mechanismů se zaměříme na výstavu, která se konala v prestižní Moravské galerii v centru Brna v roce 2001. ${ }^{5}$

Na osmnácti panelech výstava představila historii a současnost určitých etnických minorit žijících v Brně. Přítomnost těchto menšin byla navíc ilustrována vystavenými pracemi ,dětí z etnických menšin“. Spolu s Armény, Bulhary, Chorvaty, Mad’ary, Němci, Poláky, Romy, Řeky, Slováky a Židy byly do této exemplifikace multikulturní povahy Brna zahrnuty i dvě menšinové náboženské organizace - Islámská nadace a ruská Pravoslavná církev. Výstava si nekladla za cíl poskytnout podrobný portrét životního stylu menšin; uspořádání panelů spíše zdůrazňovalo emblematické znázornění etnických specifik těchto minorit. Z tohoto aranžmá bylo zřejmé, že organizátoři se pouze snažili různými př́íklady poukázat na rozmanitost ,kultur sousedících v jednom městě“. Významy, které se v diskurzu organizátorů artikulovaly, můžeme zrekonstruovat s pomocí katalogu výstavy. Katalog zdůrazňuje, že výstava pramenila $\mathrm{z}$ osobní zkušenosti pořadatelů s malým veřejným povědomím o skutečné etnické diverzitě prrítomné v Brně. Přesněji řečeno, organizátoři chtěli touto výstavou čelit nevědomosti těch, kteří si neuvědomují, že v Brně v současnosti spolu s ,většinovou společností“ žijí i jiné „etnické menšiny“ než Romové. Výstava výslovně stavěla na předpokladu, že poznání sdílené minulosti a uvědomění si současné etnické různorodosti zlepší „soužití majoritní společnosti s etnickými minoritami“".

Pro konstrukci etnokulturních identit má význam několik aspektů této události. Za prvé je to způsob klasifikace, který ovládá diskurz této události. Jinými slovy jde o způsob mapování multikulturní diverzity. Výstava na první pohled představovala a oslavovala brněnskou kulturní rozmanitost tím, že se soustředila na etnické a náboženské menšiny, které ve městě 
žijí. Avšak domněnka, že jazyk výstavy patřil do diskurzu, který pojímá multikulturní společnost $\mathrm{v}$ termínech etnické a náboženské diverzity, je mylná. Představa multikulturní společnosti, tak jak je vyjádřena v diskurzu výstavy, nemá duální (tj. multietnickou a multináboženskou) povahu. Přestože jsou kulturní identity pojímány v etnokulturní i náboženské formě, ${ }^{6}$ pouze etnokulturní identity vytvářejí kulturní diverzitu. Význam náboženských identit se zdá být odvozen od jejich role v reprodukci identit etnokulturních. Jak Islámská nadace, tak ruská Pravoslavná církev byly do výstavy zahrnuty proto, že hrají významnou roli v kultuře některé z etnických menšin. Diskurz výstavy reprezentuje kulturní diverzitu tak, jako by to byla v podstatě diverzita etnická. Tato domněnka objasňuje, proč jiné církve a náboženská hnutí na výstavě chyběly a proč byly v tomto diskurzu nemyslitelné jako prvky multikulturní společnosti. Diskurz výstavy vylučuje možnost situovat dominantní církve do stejného sémantického pole jako instituce etnických menšin.

Vedle historicky dominantních církví byla symptomatická také nepřítomnost jiných subjektů. Zdá se, že do pole kulturní diverzity nebyli začleněni Češi a Moraváci. Neměli na výstavě žádné panely; presto byly tyto etnokulturní identity prítomny pod pseudonymem, „většinová společnost“ (který organizátoři používali v katalogu výstavy, na webových stránkách festivalu apod.). Tento pseudonym umožňuje symbolické přemístění - podobně jako v př́ípadě dominantních identit náboženských - dominantních etnokulturních identit ze sémantického pole, v němž jsou umístěny identity etnických Druhých. Tento symbolický přesun odkrývá druhý aspekt diskurzivní konstrukce identit - specifický modus symbolického panství. Jinými slovy odhaluje, jak je pole multikulturní diverzity hierarchicky strukturováno.

Výroky jako „soužití většinové společnosti s etnickými menšinami“ znázorňují hierarchickou strukturu vztahů na poli kulturní diverzity. Pole etnokulturních identit je rozděleno na segregované prostory „nás“ (většinové společnosti) a ,jich“ (menšin). Tyto prostory nejsou pouze segregované, ale jsou také hierarchicky uspořádané. Jeden ze subjektů soužití je umístěn do privilegovaného postavení, nebot' jeho vztah k ostatním je považován za rozhodující. Tato hierarchie je legitimizována reinterpretací identity dominujících prostřednictvím pseudo-demokratického konceptu - většinové společnosti. Tímto způsobem je ustavující princip hierarchie reprezentován jako by šlo o pouhou kvantitu. Dominantní etnokulturní identity jsou současně s tím znázorňovány jako by byly post-etnickými kulturními identitami. Pseudonym „většinová společnost“ vytváří symbolickou hranici, jež rozlišuje mezi dominantními a minoritními identitami. Dominantní identity jsou tímto pseudonymem odlišovány od minoritních identit na základě představy, že reprezentují kolektivitu, která je rozsáhlejší a je „něčím víc“ než kolektivita etnická. Pseudonym „majoritní společnost“ se snaží vyvarovat - ale zároveň ji podporuje - hierarchické struktury nacionalistických diskurzů, která operuje s taxonomií kolektivit založenou na metanarativu historického vývoje. Podle této nacionalistické taxonomie byly etnické identity charakteristické pouze pro méně rozvinuté populace, zatímco národní identita je chápána jako „něco víc“ než identita etnická. Pseudonym „většinová společnost“ zastupuje dominantní sociální identitu, která si nárokuje zvláštní odlišnost od etnických identit menšin. Ve skutečnosti pseudonym ,většinová společnost“ zastupuje českou národní identitu. Klíčovou otázkou je, zda konkrétně tato forma české národní identity (tak, jak je artikulována v diskurzech „většinové společnosti“) je „něčím víc“ než jen ideologickou reprezentací dominantní české etnokulturní identity. 
Naše interpretace zmíněné výstavy ukazuje, jak určitý diskurz současně ustavuje taxonomické diference a hierarchické distinkce. Jedním z ústředních témat představovaných diskurzem výstavy byla etnokulturní kolektivita. Taxonomické diference i hierarchické distinkce byly konstruovány ve vztahu k symbolickému přívlastku etnicity. V souladu s tím byla multikulturní diverzita (s použitím př́kladu Brna) reprezentována jako diverzita etnokulturní. Hierarchie mezi dominantními a minoritními kulturami nabyla konkrétní formy v rozlišování mezi etnokulturními identitami, které již etnicitu překonaly, a těmi, které jsou pouze etnické či stále ještě v etnicitě uvězněné. Ústřední paradox této hierarchické distinkce spočívá ve skutečnosti, že dominantní sociální identita se považuje za etnickou a zároveň za něco víc než jen etnickou. Pro náš argument je však zásadní to, že etnicita představuje referenční rámec jak pro minority, tak pro dominantní identity. Abychom mohli analyzovat utváření minoritních etnokulturních identit, je vždy nutné hovořit také o utváření etnokulturních identit dominantních.

Složité vztahy mezi různými etnokulturními identitami vytvářejí ,pole etnicity“. ? Z výše zmíněného analyzovaného prŕkladu by mělo být zřejmé, že v tomto poli jsou př́itomny dominantní i minoritní etnokulturní identity. K pochopení, ale také ke zrrízení diskutované výstavy je potřeba jisté obeznámenosti s polem etnicity. Předpokládáme, že organizátoři i návštěvníci výstavy měli určitý smysl pro etnicitu, což jim umožnilo vstoupit do tohoto sociálního pole, být schopni hrát jeho hru a angažovat se v ní. ${ }^{8} \mathrm{~V}$ následující části textu se pokoušíme porozumět tomu, co tento smysl pro etnicitu je, jak funguje jako sociální konstrukce a v jakém smyslu může být intersubjektivním produktem institucí a diskurzů.

\section{SmysI pro etnicitu: praktické vědění o etnokulturních atributech}

Smysl pro etnicitu může být nejlépe charakterizován jako akt klasifikace praktikovaný samotnými sociálními aktéry. Jestliže chceme jako sociologové porozumět tomu, jak pole etnokulturních identit funguje, to jest, jestliže chceme teoretizovat o utváření etnokulturních identit, musíme vzít v úvahu praktické vědění o společnosti produkované a používané samotnými sociálními aktéry (Bourdieu 1990). Smysl pro etnicitu, jako forma praktického vědění, je přítomen nejen ve způsobech, jakými si představujeme společnost a svět kolem nás, v narativech o nás a druhých, v našich každodenních sociálních interakcích, ale také v institucích sociálního systému, jako jsou cenzy, dotazníky a administrativní praktiky. Skrze tyto praktiky je společnost běžně pojímána a zakoušena jako prostor etnokulturních vztahů, jako pole etnokulturních identit. V tomto praktickém smyslu je společnost prostorem, kde (my) Češi a (oni) Romové žijí, kde (my) Slováci a (oni) Mad’aři bojují, kde (my) Mad'aři a (oni) Židé pilně pracují.

Ve své základní formě je smysl pro etnicitu přítomen v každodenních i spontánních konverzacích. „Jste už v Iráku?“, mohl by se zeptat přítel nebo prrítelkyně ohledně nedávné politické situace (válka Iráku v roce 2003) a myslet tím ve skutečnosti, zda už jsou tam české nebo mad'arské vojenské jednotky. Tato otázka umíst’uje debatu o vzdálených událostech do lokálního pole etnokulturních identit. V tomto př́ípadě smysl pro etnicitu coby klasifikační akt používá metonymické funkce osobního zájmena „vy“, které zastupuje celou etnokulturně pojímanou kolektivitu a vytváří sociální svazek mezi konkrétní osobou a etnokulturní kolektivitou, k níž ona či on náleží. Dobře známý výrok fotbalových fanoušků „Kdo neskáče, není 
Čech!“ ustavuje pole etnicity skrze hranice mezi národními fotbalovými týmy a, na rovině mentální, vylučuje možnost jednat v rozporu s vlastním smyslem pro etnicitu. V diskurzu fanoušků by bylo nemyslitelné, aby Čech podporoval italský fotbalový tým, protože jiné než národnostní identity, například náboženské identity, jako je katolictví, jsou považovány za irelevantní. Smysl pro etnicitu je př́tomen také ve zdánlivě neškodném tvrzení „Židé si dnes připomínají oběti holocaustu“. Tento výrok demonstruje exkluzivní charakter etnokulturní klasifikace, nebot' jeho logika „,vytváření Druhých“ spočívá v předpokladu, že truchlit a připomínat si holocaust je etnokulturně specifikovatelné jednání a co víc, mělo by se s ním takto zacházet. Držet smutek v Den připomínky holocaustu ze sdíleného „pocitu lidství“ či „pocitu občanského společenství" je podle etnokulturního diskurzu nemyslitelné. ${ }^{9}$

Jak naznačují výše zmíněné prííklady, smysl pro etnicitu může být chápán jako součást doxické zkušenosti, která vidí zakoušený stav a rozdělení světa jako nutné, či jinými slovy, přirozené (Bourdieu 1992b). Doxická zkušenost nejen znázorňuje, ale také vytváří svět, v němž žijeme, skrze každodenní diskurz. Na tomto místě je třeba učinit dvě obecné, úzce související poznámky. Za prvé, je nutné zdůraznit, že praktické vědění sociálních aktérů nelze redukovat na pouhý odraz sociální reality. Smysl pro etnicitu není pouze produktem uvědomění si toho, že ve skutečném světě existují etnické kolektivity, toto praktické vědění spíše sociální skutečnost etnokulturních identit ustavuje. Jako všechny formy vědění je i praktické vědění o etnicitě také aktem interpretace (neboli aktem konstrukce významu), který používá „myšlenková a výrazová schémata“ (tj. jazyk) k reagování na výzvy sociálního světa. Tento proces je nemyslitelný bez tvořivé činnosti aktéra. To znamená, že sociální aktéŕi nereagují mechanicky na podmínky své existence; odpovídají aktivně prostřednictvím své praktické strukturující činnosti. Je proto podstatné reflektovat, jak vědění o etnicitě přispívá $\mathrm{k}$ sociální realitě etnokulturních identit.

To nás dovádí $\mathrm{k}$ druhému bodu. Vědění o etnicitě, které tento text zkoumá, není teoretickou, ale praktickou formou vědění. To znamená, že vědění o etnicitě nelze redukovat na teoretické myšlení používající systematické formy a kategorie, především proto, že smysl pro etnicitu je zaměřen na praxi. Není vytvářen kvưli čisté a pravdivé reprezentaci skutečnosti; kritérii tohoto praktického vědění nejsou jeho vnitřní koherence či pravdivost ve vztahu k objektivnímu světu. Jeho kritéria relevance je třeba hledat spíše $\mathrm{v}$ jeho praktické použitelnosti. Řečeno jinak, smysl pro etnicitu je př́tomen nejen v myslích lidí, ale také v jejich jednání - je ztělesněn v praktikách, které produkují jak (další) vědění, tak instituce. Jako internalizované schéma myšlení a vyjadřování se smysl pro etnicitu neustále provádí/vykonává v praktikách každodenního života, podobně jako $\mathrm{v}$ institucionalizovaných rituálech a slavnostních ceremoniích. V důsledku toho je smysl pro etnicitu zakódován v habitu (Bourdieu 1984), je to dispozice určitým způsobem klasifikovat svět a jednat v něm. ${ }^{10}$ Hovořit o smyslu pro etnicitu jako o součásti habitu vyžaduje reflexi toho, jak praktické vědění sociálních aktérů o etnicitě přispívá k jejich etnokulturní identitě. ${ }^{11}$ Bez tohoto praktického vědění o etnicitě nemůže existovat žádná etnokulturní identita.

Praktická relevance smyslu pro etnicitu spočívá v jeho sociálním účinku, sociální užitečnosti a použitelnosti. Funguje jako návod pro základní sociální orientaci. Jako takový má závažné důsledky pro sociální jednání, některé cesty označí jako nebezpečné, jiné jako dobré a hodné následování. Pouze omezené množství praktik, vztahů a idejí je identifikováno jako 
adekvátní; vztahy solidarity a loajality jsou možné pouze za specifických omezení. Smysl pro etnicitu jako nástroj sociální orientace určuje místo člověka ve světě, nebot' jej/ji vztahuje k určité etnokulturní kolektivitě. Smysl pro etnicitu tedy nedefinuje pouze místo naše, ale i místo ostatních/druhých. Právě toto vědomí vlastního místa a místa druhých ustavuje pole etnických pozic a etnických hranic. Smysl pro etnicitu působí v souladu s vírou, že každá osoba musí přirozeně/nezbytně náležet $\mathrm{k}$ etnokulturní kolektivitě. ${ }^{12} \mathrm{~V}$ tomto smyslu není žádný člověk bez etnokulturní identity - každý a každá má své vlastní správné místo v poli etnicity.

Coby nástroj sociální orientace není smysl pro etnicitu pouze smyslem pro etnokulturní diferenci, je také smyslem pro etnokulturní distinkci. ${ }^{13}$ Smysl pro distinkce vyžaduje, podle Bourdieuho, „aby byly určité věci spojovány a jiné drženy odděleně, což vyloučí všechny mezaliance a všechna nepřirozená spojení - tj. Všechna spojení odporující obvyklé klasifikaci“" (Bourdieu 1984: 474). Smysl pro etnicitu je vzájemně propojen se schopností rozlišovat mezi sociálně vhodnými/nevhodnými společenstvími a spř́zněnostmi. Tato kompetence činit etnokulturní distinkce může být přirovnána ke kompetenci vyžadované v prakticko-estetických soudech. Smysl pro etnicitu, podobně jako vkus, dává vzniknout určitým úsudkům o tom, co je a co není príjatelné. Když tvrdíme, že smysl pro etnicitu není pouze smyslem diference, ale také smyslem distinkce, poukazujeme na hierarchickou strukturu pole etnokulturních identit. Některé pozice v tomto poli jsou horizontální, ale jiné jsou uspořádány hierarchicky. Některé etnokulturní identity jsou považovány za rovnocenné s „naši“ “ etnokulturní identitou, ale jiné jsou chápány jako kvalitativně odlišné. Jak jsme ukázali v úvodní analýze výstavy MIPu, kvalitativní distinkce může v různých diskurzech nabývat různých podob: může jít o distinkci mezi menšinami a většinovou společností, mezi národy a etnickými skupinami nebo mezi historicky rozvinutými a méně rozvinutými národy. Ústřední (obvykle naše) etnokulturní identita se nemusí automaticky nalézat na vrcholu hierarchie. Například středoevropské národní identity se vyznačují syndromem malých národů, které nejsou, ve svých moderních narativech, umístěny na vrcholu hierarchie, ale pomalu se $\mathrm{k}$ této pozici blíží. ${ }^{14} \mathrm{Od}$ tohoto předpokladu je jenom krůček k praktické domněnce, že existence i hierarchická distinkce etnokulturních kolektivit jsou přirozené/nutné. Proto má každý své správné místo v hierarchicky řazeném poli etnicity.

Lze shrnout, že smysl pro etnicitu, jako nástroj sociální orientace, působí prostřednictvím praktické znalosti etnokulturních diferencí a etno-kulturních distinkcí. Proto bude osoba s obvyklým smyslem pro etnicitu schopna rozeznávat etnokulturní identitu druhých lidí a bude moci činit soudy o etnokulturních atributech osob a objektů. Jinými slovy praktická znalost etnokulturního pole sestává z kompetence rozeznávat určité atributy osob a objektů jako etnokulturně relevantní. Tyto soudy lze považovat za praktiky stigmatizace. Jestliže chápeme fungování stigmatizace, můžeme snadno pochopit také fungování smyslu pro etnicitu.

Stigmatizace je klasifikační praktika vystavěná kolem ústředního rysu (stigmatu), který je považován za podstatný pro identitu dané osoby a její předpokládané budoucí chování (Goffman 1986). Stigmatizační praktiky izolují specifické atributy od ostatních, které jsou klasifikovány jako nedůležité nebo dokonce zůstanou nerozpoznány. Podobně i smysl pro etnicitu identifikuje osoby jako členy etnokulturní kolektivity na základě jistých atributů. Rozpoznání etnokulturních atributů je vždy založeno na interpretativním výběru z rozsáhlého souboru potenciálně dostupných atributů. $V$ pozadí této selektivní klasifikace stojí sdílené vědění, které lze odhalit skrze jev nazvaný „princip pertinence“ (př́padnosti) (Bourdieu 1984). Lze jej vypozorovat například 
v diskurzivních událostech, $\mathrm{v}$ nichž posluchači spontánně potvrdí relevanci nálepky vyjádřené v soudu mluvčího. Vtipy o Romech a Židech (přítomné v české společnosti také v současných každodenních konverzacích nebo mediálních zábavných pořadech) fungují na základě tohoto principu. Tyto vtipy působí pouze ve vztahu ke sdílenému vědění, které je pozadím osvětlujícím typické chování, osobní charakteristiky, tělesné rysy a zvyky těch, kdo jsou objektem zesměšnění. Pouze ti, kdo toto vědění sdílejí, mohou vtip dekódovat a zasmát se mu.

Ve středoevropských společnostech je etnokulturní identita obvykle rozpoznávána ve vztahu k jazyku užívanému danou osobou, k „tělesnému image“ a/nebo k symbolickým reprezentacím původu. ${ }^{15}$ Soudy klasifikující osoby ve vztahu k užívanému jazyku nevyžadují pouze schopnost rozeznat konkrétní etnokulturní či národní jazyky, ale obvykle také schopnost rozpoznat cizí či regionální př́zzuk a omezenou slovní zásobu. Kompetenci ke klasifikování lidí ve vztahu k jejich „„ělesnému image“ nelze redukovat na klasifikatorní soudy o jejich fyzickém těle. Je mnohem vhodnější hovořit o rozpoznávání sociálního a kulturního vpisování na fyzická těla osob, o klasifikaci těla coby součásti osobního habitu. Etnokulturní druzí, které potkáváme, obvykle nejsou nazí. V praktikách etnokulturního rozpoznávání jsou oděv, účes a vzhled neoddělitelné od čistě fyzického těla, nebot' jsou rovnocenně relevantními objekty posuzování. Poslední forma kompetence je spojena s rozpoznáváním symbolických reprezentací původu. Může se jednat o jména, vyjádření sebe-identity v životních př́ibězích či každodenních konverzacích, o administrativní informace o osobní identitě ${ }^{16}$ obsažené v dokumentech (rodném listě, občanském průkazu, cestovním pase atd.). Tyto symbolické reprezentace slouží k dotvrzení etnokulturní identity připsané osobě ve vztahu k jejímu/jeho jazyku a/nebo tělesnému image. V některých př́ípadech pak tyto symbolické reprezentace ukazují na odlišnou etnokulturní identitu než je ta, kterou naznačuje jazyková performance či tělesný image. Takovéto prrípady jsou pro nás obzvláště důležité, nebot' ukazují, že přiznání etnokulturní identity není nezávislé na institucích, které osobám přidělují určité známky identity, a - což je ještě důležitější - není nezávislé na diskurzu, jenž vyžaduje upřímnost v sebe-vyjádření. ${ }^{17}$

\section{Budování smyslu pro etnicitu: symbolická moc institucí a diskurzů}

Žádný smysl pro etnicitu se neobejde bez kompetence rozpoznávat etnokulturní identitu druhých lidí, která vyžaduje praktickou znalost etnokulturních atributů. Tato kompetence i praktická znalost jsou produkovány a kultivovány $\mathrm{v}$ určitých institucích a diskurzech. Lidé se nerodí se schopností rozpoznávat specifické etnokulturní či národní jazyky a cizí a regionální akcent. Tato kompetence se získává v procesech socializace. Podobně i praktiky uživání jazyka, atributy „tělesného image“ stejně jako symbolické reprezentace původu jsou objekty praktického vědění, které je kultivováno v diskurzech a předáváno mladší generaci skrze instituce socializace. Pokud tedy chceme porozumět tomu, jak se konstruuje smysl pro etnicitu, musíme se zaměřit na diskurzy, které vytvářejí praktické vědění o etnokulturních atributech, a na instituce, které toto praktické vědění předávají mladé generaci. Stejně důležitá se zdá být otázka, jak se toto praktické vědění reprodukuje v každodenním životě. Jsme toho názoru, že rodina, vrstevnické skupiny, škola i média masové komunikace hrají v tomto procesu významnou roli. Proto se konkrétní etnokulturní identity a na obecnější rovině sdílený smysl pro etnicitu vytvářejí současně. 
Spojení mezi smyslem pro etnicitu a institucionalizovanými formami vědění se odhaluje v ambivalentních situacích, kdy jsou úsudky o etnokulturních identitách znejistěny, tedy v situacích, kdy individuální etnokulturní atributy nejsou snadno rozpoznatelné a kdy se jedná o takzvaný smíšený etnokulturní původ. V těchto př́padech - kdy princip pertinence nefunguje a úsudky o etnokulturní identitě nejsou zřejmé -, je třeba tyto soudy ospravedlnit, částečně z toho důvodu, že v těchto nejasných př́padech mohou být úsudky a jejich ospravedlnění napadeny jinými účastníky diskurzu. Jaká bude předpokládaná etnokulturní identita dítěte ze smíšeného manželství, například romské matky a českého otce, nebo osoby, jejíž rodiče jsou klasifikováni jako Mad’ar a Češka? V těchto př́ipadech se úsudek řídí diskurzy expertního vědění nebo institucionálně připsanými nálepkami, které najdeme například v osobních dokumentech. Obvykle je jedna z, ,původních“ etnokulturních identit vymazána a konstruuje se očištěná linie původu. ${ }^{18}$ Lidé jsou nuceni vybrat si, nebo jsou jednoduše klasifikováni institucionálně jako náležející k jedné ze svých duálních ,původních“ etnokulturních identit. Tyto př́klady odhalují, že instituce a diskurzy etnokulturní identitu nejen registrují a popisují, ale že tyto sociální identity skutečně vytvářejí.

Avšak ambivalentní nemusí být jen etnokulturní identita Druhého. Pocity nejasnosti se mohou objevit i v př́běhu vlastní identity, když člověk bud' neočekávaně objeví svou dvojí linii původu nebo se snaží vyřešit dilema své autentické etnokulturní přináležitosti. Dobrým př́ikladem možnosti, jak získat novou etnokulturní identitu skrze kulturní asimilaci a být přijat/a do nové etnokulturní kolektivity, je ve střední Evropě změna rodného jména. Nicméně pro druhou či třetí generaci asimilovaných se může autentický etnokulturní původ stát $\mathrm{v}$ mnoha př́ipadech předmětem pátrání. Také tyto př́pady ukazují, že instituce a diskurzy (zde například v podobě expertního vědění nebo v podobě nostalgických narativ kolujících v etnokulturních spolcích) výrazně přispívají ke zvládnutí potenciální krize identity. ${ }^{19}$ Pro sociologickou perspektivu je klíčové, jak jsou tyto formy vědění a instituce, které pomáhají urovnávat dilemata spojená s identitou, budovány. Proto je třeba zaměřit naši pozornost na institucionální struktury modernity, přesněji na moderní strategii národního sjednocování.

Strategie národního sjednocování hraje klíčovou úlohu v kultivaci jednotlivých etnokulturních identit i obecného smyslu pro etnicitu ve střední Evropě. Role této strategie nebyla významná pouze v minulosti, ale má podobný význam i dnes. Sociologický diskurz si je vědom kreativní role, kterou nacionální hnutí 19. a raného 20. století sehrály při budování národních identit ve střední Evropě - národní identity byly nacionalistickými hnutími zaváděny jako identity etnokulturní. Kromě formativní fáze zavádění (vynalézání) je třeba si všimnout také fáze reprodukce identity. Zaměřit se na reproduktivní fázi strategie národního sjednocování znamená soustředit se na instituce a diskurzy, které pěstují, kopírují a uchovávají tyto národní identity v podobě etnokulturních identit - tedy studovat, jak strategie národního sjednocování buduje pole etnicity. Je zřejmé, že kromě nacionálních hnutí tyto instituce a diskurzy zahrnují také instituce a diskurzy ovládané státem a kontrolované komerčními trhy.

Jedním z klíčových prvků strategie národního sjednocování je jazykové a kulturní sjednocení společnosti. Oproti místním dialektům, kulturám a identitám je vyzdvihován primát národního jazyka, kultury a identity. Tato strategie za pomoci reinterpretace vede k podrobení tradiční místní kultury a identity. Ty jsou mytologizovány jako autentické zdroje kultu- 
ry a přesunuty do minulosti coby exotizovaný folklor. Jsou v nich nacházeny jakési známky autenticity, které je třeba uchovávat jako muzejní exponáty, spíše než kultivovat jako př́hodnou základnu pro moderní vývoj národa. Předmětem normalizace není pouze unifikace jazyková, ale celková unifikace kulturní. Jsou ustavovány a prosazovány národní instituce a diskurzy, jak ve smyslu „národní coby teritoriální“ (přítomný kdekoli na území daného státu), tak ve smyslu nacionální ideologie (která chápe národy jako antropomorfní subjekty a upřednostňuje národní identitu coby základní zdroj loajality a solidarity). Národní normalizace znamená celo-národní (územní) šíření určitých forem vědění, praktik a identity - např́íklad zaváděním národní kultury paměti institucionalizované v muzeích a památnících. Dále je pro tento proces rozhodující rozvoj institucionálního pole státní správy a vzdělávání, stejně jako vytvoření celonárodního komerčního a pracovního trhu. Cirkulace diskurzů, textů, knih a novin ilustruje normalitu etnokulturních identit. Např́klad diskurzy o historii a literatuře - které zastupují historické a literární pole v daném etnokulturním modu - hrají klíčovou roli v kultivaci smyslu pro etnicitu mezi studenty základních a středních škol.

Abychom dekonstruovali smysl pro etnicitu, lze klást otázky, které odhalují institucionální formy vědění v pozadí klasifikatorních soudů aktérů: Jak jste zjistila, že jste Židovka?20 Kdo vám řekl, že jste Rom? Jak víte, že vaši sousedé jsou Bulhaři? Jak víš, že jsi českého původu? Jak víte, co znamená být Mad’arem? Kde jste získala své znalosti o vietnamské mentalitě? Na tyto otázky nelze odpovědět bez účasti na specifických diskurzech, které produkují vědění o poli etnicity, a bez přijetí institucionalizované autority takového vědění. Proto když hovoříme o diskurzech a institucích, hovoříme zároveň o cirkulaci praktického vědění o etnokulturních diferencích a distinkcích ovlivňovaných mocenskými pozicemi.

\section{Dvojí tvář sociální inkluze: institucionální integrace a symbolická exkluze}

Jak národní unifikace, tak multikulturní strategie sociální inkluze nutně reprodukují pole etnicity i smysl pro etnicitu. Procesy sociální inkluze ${ }^{21}$ jsou nevyhnutelně určeny relativní blízkostí individuálních etnokulturních identit v poli etnicity. Př́íklady smíšených sňatků a kulturní asimilace ukazují, že jednotlivé etnokulturní identity jsou vůči sobě navzájem určitým způsobem otevřené - jednotlivé etnokulturní hranice se selektivně uzavírají a otevírají. ${ }^{22}$ Procesy sociální inkluze nutně vedou k úpravě vztahu mezi jednotlivými etnokulturními identitami. Politické strategie sociální inkluze tím, že integrují menšinové etnokulturní identity, nevyhnutelně pozměňují celou strukturu pole etnicity. Pokud tato restrukturalizace nenastává, pak - ze sociologického hlediska - nemůžeme hovořit o sociální inkluzi.

V následující části textu máme v úmyslu ukázat, jak diskurzy a instituce sociální inkluze reprodukují smysl pro etnicitu. Pokud se menšinové etnokulturní identity úspěšně přizpůsobí (snahou menšinových aktivistů) smyslu pro etnicitu př́tomnému v dominantních diskurzech a institucích, pak mají dobrou šanci na sociální inkluzi. Vztah mezi procesy sociální inkluze a reprodukcí smyslu pro etnicitu znázorníme na př́íladu instituce romských poradců a asistentů. Instituce romského poradce a romského asistenta zavedla česká vláda v roce 1997. Titul „romský poradce a asistent“ naznačuje, že poradce (poradkyně) je obvykle osoba s romskou etnokulturní identitou a že bude radit a pomáhat v místní romské komunitě (Sirovátka a Hamar 2001). 
Oficiální sociální funkcí romských poradců a asistentů je integrace romské populace do české společnosti pomocí řešení (většinou sociálních) problémů romské komunity. Zajišt'ují komunikaci a jsou prostředníky mezi místní správou a místními romskými komunitami. Poradci jsou zaměstnáni u místní správy, zatímco asistenti fungují jako sociální pracovníci ve školách a romských čtvrtích. Ostatní státní úředníci zaměstnaní u místní správy mají snahu předávat veškeré záležitosti spojené s osobami s romskou etnokulturní identitou těmto poradcům a asistentům, ačkoliv dříve než byla tato instituce zřízena, spadaly tyto úkoly a povinnosti do jejich kompetence. Tento přesun kompetencí probíhá spontánně, jinými slovy, není výsledkem organizační restrukturalizace pracovníků místní správy.

Instituce romských poradců a asistentů skrytě reprodukuje smysl pro etnicitu. Reprodukuje praktickou znalost diference a distinkce mezi českou a romskou etnokulturní identitou a také reprodukuje smysl pro etnicitu nejen u romských klientů a asistentů, ale také u osob s českou a jinou ne-romskou etnokulturní identitou. Za prvé státní úředníci, kteří pracují pro stejnou místní správu, mají př́mou zkušenost s institucí romských poradců a asistentů. Za druhé ostatní lidé, kteří slyšeli nebo četli o práci romských poradců a asistentů, získali nepřímou zkušenost s touto institucí. V obou př́padech zmíněná instituce reprodukuje smysl pro etnicitu pouze tehdy, pokud je pro tyto osoby určitým způsobem relevantní ${ }^{23} \mathrm{~V}$ př́padě místních státních úředníků může být tato instituce relevantní přinejmenším s ohledem na jejich organizační zájmy. Budou mít zřejmě zájem přesunout své pracovní povinnosti na nově př́ichozí. Ale jaký význam může mít tato instituce pro lidi, kteří s ní mají pouze neprímou zkušenost? Jaký zájem by na ní mohly tyto osoby mít?

Z výše řečeného vyplývá, že smysl pro etnicitu - použijeme-li Bourdieuho slovní hru coby selektivní připisování etnokulturních atributů je neoddělitelný od materiálních a ideologických zájmů. Důvody, proč jsou pro nás některé atributy zajímavé, nejsou nikdy zcela nezávislé na našem zájmu považovat tyto atributy za relevantní (Bourdieu 1984). Přesněji řečeno neznamená to, že určité osoby nutně získají nějaké osobní výhody, když budou uznávat některé specifické atributy jiných osob. Tyto zájmy jsou spíše vyjádřeny v diskurzivních strukturách taxonomických diferencí a hierarchických distinkcí, které jsou vnitřně dané strukturálním pozicím určitého sociálního pole. V našem př́kladu se tyto zájmy vztahují ke strukturálním pozicím v poli etnicity. Menšinové etnokulturní identity mohou být definovány na základě své podřízené strukturální pozice v tomto poli. Smysl pro etnicitu, který chápe některé kolektivity jako menšiny, je artikulován z perspektivy dominantních pozic. To však neznamená, že se této dominantní perspektivě nelze postavit. Sociální identity nejsou pouze hybnými silami v pozadí sociálních bojů, jejich definice a reprezentace je také nástrojem sociálního boje (Bourdieu 1992a). Navíc tento klasifikační boj není pouze bojem dominantních proti podrobeným - kteří jsou obvykle považováni za bezmocné -, ale zahrnuje také triky a praktiky odporu ze strany podrobených. Praktiky vytváření etnokulturní identity jsou proto vzájemně propojeny s ideologickými i hmotnými zájmy všech účastníků pole etnicity. Přesněji řečeno, praktické vědění o etnicitě je budováno v souladu se strukturální pozicí jeho nositelů. Proto vyvstává otázka: čím zájmem je představovat tyto kolektivity jako etnokulturní minority?

Další zajímavý rys instituce romských poradců a asistentů spočívá v jejím potenciálu překračovat dominantní smysl pro etnicitu, který považuje Romy za homogenní kolektivitu. Tento předpoklad homogenity není napadán přímo v rovině diskurzu, ale je překračován 
institucionální praxí privilegizace místních lidí při obsazování pozice romských poradců $\mathrm{a}$ asistentů. Tato institucionální praxe se může $\mathrm{v}$ daném prŕípadě střetnout $\mathrm{s}$ místní etnokulturní diverzitou komunit oficiálně klasifikovaných zastřešujícím termínem: Romové. Pro tuto praxi je důležitější zaručit fungování instituce za použití místní taktiky spíše než se stavět do opozice vi̊či homogenizujícímu diskurzu uplatňováním reformních strategií. Tato homogenizace diferencí a distinkcí je klíčovým rysem smyslu pro etnicitu, který funguje v oficiálních institucích i v žitém světě. Některé diference a distinkce - např́klad mezi Olachy a Rumungry - jsou interpretovány jako vnitřní záležitosti dané kolektivity, a tudíž nejsou vnímány jako podstatné. Místní menšinové kultury si tak mohou vytvářet vlastní smysl pro etnicitu, odlišný od oficiálně institucionalizovaného smyslu. Jejich praktické vědění o etnokulturních identitách může zdůrazňovat diference a distinkce, které jsou dominantní perspektivou vnímány jako irelevantní..$^{24}$

Co se týče skupinových hranic, ignorování vnitřního dělení a důraz na externí diference, které charakterizují homogenizující klasifikace, nejsou nutně nástroji exkluze. Homogenizující efekt se neomezuje na etnokulturní klasifikace, nebot' diskurzy utváŕející občanské identity také provádějí homogenizující praktiky například tehdy, když přiznávají rovná práva všem osobám patřícím do určitého politického společenství. Inkluze občanů do politického společenství závisí na ignorování určitých vnitřních rozdělení mezi těmi, kdo mají být zahrnuti. Podobně i smysl pro etnicitu může současně vytvářet exkluze i inkluze.

$\mathrm{Z}$ tohoto hlediska je třeba upozornit na symbolickou moc té formy smyslu pro etnicitu, jež pojímá etnokulturní kolektivity jako biologicky či geneticky ukotvené. Ideologie čistého etnokulturního původu může být $\mathrm{z}$ vědeckého hlediska nesprávná, nicméně má reálné sociální důsledky. Praktickým účinkem této ideologie je popření volby a svobodné vưle týkající se etnokulturní identity. Smysl pro etnicitu založený na praktickém vědění o etnokulturní čistotě - i když se jedná o mýtus - může přispívat $\mathrm{k}$ tomu, co podle ideologie čistě etnokulturního původu existuje, to jest k etnokulturně uzavřeným společenstvím. Lze toho dosáhnout napríiklad sňatkovými preferencemi a ovlivňováním sňatkové volby potomků. Jinými slovy předpokládaná skutečnost etnokulturního původu je vlastně utopií čistého etnokulturního společenství. Je to něco, co ideologický diskurz hledá v minulosti a co označuje jako autentickou hodnotu; přičemž ve skutečnosti jde o normativní vizi, kterou je třeba realizovat v budoucnosti. Ideologie používá následujícího triku: popis minulosti je ve skutečnosti předpisem pro budoucnost. Je však důležité upozornit na to, že tato utopická ideologie čistého etnokulturního původu je prítomná jak v dominantních, tak v menšinových etnokulturních diskurzech.

Pole etnokulturních identit ve střední Evropě je strukturováno soudy o tom, kdo vypadá a/nebo hovoří odlišně nebo má odlišný etnokulturní původ. Z hlediska sociální inkluze menšinových kultur je klíčové, do jaké míry jsou tyto etnokulturní atributy rozpoznávány a chápány jako významné, přesněji do jaké míry a $\mathrm{v}$ jakých kontextech jsou tyto atributy považovány pouze za významné znaky etnokulturních diferencí, nebo spíše viděny jako distinkce. ${ }^{25}$ Smysl pro etnicitu pravděpodobně bude ve středoevropských společnostech i nadále přitomen, avšak stále existuje možnost, že etnokulturní identita druhých bude v určitých situacích rozpoznávána, ale ignorována. To je možné díky skutečnosti, že mohou existovat sociální interakce, v nichž se vytváŕí pouto solidarity mezi aktéry různých etnokulturních identit např́iklad na základě sdílené víry $\mathrm{v}$ možnost vybudovat bohumilý a ctnostný pozemský svět či v př́tom- 
nost dobrých a zlých duchů v každodennosti, na základě sdílené nenávisti vůči subjektům nerespektujícím dané slovo nebo vůči cizím okupantům, na základě sdíleného přesvědčení o hodnotě individuální svobody či rodinného života, sdíleného nadšení pro určité sporty či sportovní kluby atd. Jinými slovy ve společnosti jsou př́tomné i jiné smysly pro diference a distinkce, které utvářejí jiné než etnokulturní formy sociálních identit. Existují instituce a diskurzy, $v$ nichž jsou etnokulturní distinkce přepsány sociálními identitami založenými na občanství, národě, náboženství, genderu, rodině, příbuzenství, regionu, povolání, vzdělání, politické ideologii a počestnosti. Otázkou ovšem zůstává, zda dominantní instituce a diskurzy budou dávat přednost smyslu pro etnicitu před jinými sociálními identitami.

Praktiky sociální inkluze jsou dvojznačné. Na jedné straně vedou k institucionální integraci etnokulturních menšin, na straně druhé však vedou k symbolické exkluzi těchto menšin z české národní identity. Diskurzy, v nichž čeští občané s romskou či polskou etnokulturní identitou nejsou vnímáni jako Češi, vylučují možnost dvojité česko-romské či česko-polské identity. Tento př́ípad samozřejmě nastává pouze tehdy, je-li česká národní identita pojímána čistě jako etnokulturní identita. Vytváření minoritních a dominantních identit je neoddělitelné, jsou budovány ve stejném diskurzivním a institucionálním poli. Smysl pro etnicitu, který převládá v praktikách sociální inkluze, vede k etnokulturnímu vymezení české národní identity. Vnímá totiž menšiny jako etnokulturní kolektivity a kulturní diverzitu české společnosti pojímá v podobě diverzity etnokulturní. Tato forma sociální inkluze vede tedy k nezamýšlenému důsledku: tím, že českou národní identitu chápe jako dominantní etnokulturní identitu, vylučuje všechny ostatní - to jest menšinové - etnokulturní identity z imaginárního etnokulturního společenství českého národa. Z hlediska sociální inkluze je nejdůležitější otázkou, jestli budou diskurzy symbolické moci tematizovat duální - etnokulturní a politický - charakter české národní identity. Jinými slovy otázkou je, zda jsou oficiální diskurzy a instituce schopny formulovat rozdíl mezi „českou národnosti““ pojímanou jako etnokulturní identita a „českým občanstvím“ pojímaným jako identita politická. ${ }^{26}$ Latentní symbolická exkluze ne-etnokulturních Čechů z českého národa (představovaného jako etnokulturní společenství) získává protiváhu v podobě inkluzivních politicko-právních opatření, která zdůrazňují ne-etnokulturní charakter českého občanství, a v důsledku toho i politický charakter českého národa představovaného v podobě politického společenství občanů republiky.

\section{Poznámky}

1 Původní anglická verze tohoto článku vychází v knize The Challenge of Social Inclusion: Minorities and Marginalized Groups in Czech Society. Ed. by Tomáš Sirovátka, Budapest: Central European University Press 2005.

2 Následující seznam institucí a občanských sdružení souvisejících s etnokulturními menšinami žijícími v české společnosti nastiňuje situaci v červenci 2004 a je výsledkem našeho etnografického sběru dat:

Anglicky mluvicílamerické: Expats (Praha).

Arménské: Arménský dům (Mladá Boleslav).

Bulharské: Bulharská kulturně osvětová organizace Sv. Cyrila a Metoděje (Praha), Hyshove (Praha), Sdružení pro Bulharsko (Brno), Bulharské kulturně osvětové sdružení (Brno), Zaedno (Praha), Vazraždane (Praha). 
Běloruské: Osvětový a vzdělávací spolek Skaryna (Praha), Svaz Bělorusů v zahraničí (Praha).

Čínské: Krajanské sdružení Číňanů žijících v ČR (Praha).

Chorvatské: Sdružení občanů chorvatské národnosti (Grygov).

Jugoslávské: Společnost přátel jižních Slovanů v ČR (Brno).

Korejské: Česko-korejská křest’anská společnost (Praha).

Mad'arské: Svaz Mad’arů žijících v českých zemích (Praha, Brno, Ostrava, Plzeň, Teplice, Litoměřice), Svaz mad'arských studentů-KAFEDIK v Brně (Brno), Klub mad'arských studentů AED (Praha), Spolek Iglice Egylet (Praha).

Německé: Kulturní sdružení občanů německé národnosti v ČR (Brno), Německé kulturní sdružení, region Brno (Brno), Německý jazykový a kulturní spolek Brno DSKV (Brno), Kulturní sdružení občanů německé národnosti (Praha), Organizace Němců v západních Čechách (Plzeň), Shromáždění Němců v Čechách, na Moravě a ve Slezku (Praha), Svaz Němců, regionální skupina Hřebečsko (Moravská Třebová), Svaz Němců - region Chebsko (Cheb), Svaz Němců - severní Morava, Orlické hory (Šumperk), Svaz Němců - Liberec, Lužice - Severní Čechy (Liberec), Kruh př́atel Německa (Kravaře).

Polské: Kongres Polakůw w RC (Český Těšín), Harcerstwo Polskie w RC (Dolní Lutyně), Klub Polski (Praha), Koło Polskich Kombatantów (Horní Suchá), Macierz Szkolna (Třinec), Miejscowe Koło PZKO Karwina-Nowe Miasto (Karviná), Polonus - Klub Polski w Brnie (Brno), Polski Związek Byłych Więźniów Politycznych (Ostrava), Polskie Towarzystwo Medyczne (Karviná), Polskie Towarzystwo Artystyczne „Ars Musica“ (Český Těšín), Polskie Towarzystwo Śpiewacze Collegium Canticorum (Karviná), Polskie Towarzystwo Turystyczno-Sportowe „Beskid Śląski“ (Třinec), Polski Związek Kulturalno-Oświatowy (Český Těšín), Stowarzyszenie Dziennikarzy Polskich (Těrlicko), Stowarzyszenie Emerytów Polskich (Horní Suchá), Stowarzyszenie Młodzieży Polskiej w RC (Český Těšín), Stowarzyszenie Osób Pracujących i Uczących się za Granicą (Český Těšín), Stowarzyszenie Rodzina Katyńska (Dolní Lomná), Stowarzyszenie Szkoła Polonijna w Pradze (Praha), Towarzystwo Nauczycieli Polskich (Český Těšín), Towarzystwo Avion (Český Těšín), Zrzeszenie Literatów Polskich (Český Těšín), ZŚM Przyjaźń (Karviná), Gorole (Mosty u Jablunkova), Základní škola s polským jazykem (Třinec).

Romské: Demokratická aliance Romů v České republice (Valašské Meziříčí), Dětský hudební a taneční soubor Cikne čhave (Nový Jičín), Komunitní centrum Chánov (Most), Nedrog (Rakovník), Občanské sdružení Romodrom (Praha), Občanské sdružení Slovo 21 (Praha), Občanské sdružení Žijeme spolu v 4. ZŠ (Sokolovo), Romská misie (Plzeň), ROS - Klub (Hořice v Podkrkonoší), Romské sdružení občanského porozumění (Nymburk), Romské sdružení (Šluknov), Sdružení dětí a mládeže Romů ČR (Zlín), Společenství Jan 10 (Dolní Ždanov), Společenství Romů na Moravě (Brno), Společenství přátel časopisu Romanu džaniben (Praha), Drom (Brno), Muzeum romské kultury (Brno).

Rusinské: Společnost přátel Podkarpatské Rusi (Praha, Brno), Folklorní soubor Skejušan (Chomutov).

Ruské: Artek (Praha), Ruský klub (České Budějovice), Sdružení krajanů a prátel Ruské tradice v ČR (Praha), Sdružení ruských občanů v ČR (Brno), Asociace ruských spolků v České republice (Brno), Ruský institut (Pardubice).

Řecké: Asociace řeckých obcí v ČR (Bohumín), Lyceum Řekyň (Brno), Hellenika, nadační fond (Brno), Řecká obec v Brně (Brno).

Slezské: Matice slezská (Opava).

Slovenské: Obec Slovákov v Brně (Brno), ČeskoSlovenská scéna (Praha), Folklorní sdružení PÚC̆IK (Brno), Folklorní soubor Šarvanci (Praha), Klub slovenské kultury (Praha), Limbora - slovenské folklórní sdružení (Praha), Obec Slováků v ČR (Praha), Slovensko-český klub (Praha), Spolok Detvan (Praha). 
Ukrajinské: Sdružení Ukrajinců a příznivců Ukrajiny (Praha), Sdružení Ukrajinek v ČR (Praha), Ukrajinská iniciativa v ČR (Praha), Fórum Ukrajinců (Praha).

Vietnamské: Sdružení vietnamsky hovořících občanů ČR (Praha).

Židovské: Federace židovských obcí (Praha), Židovské obce (Praha, Brno, Děčín, Karlovy Vary, Liberec, Olomouc, Ostrava, Ústí nad Labem, Teplice, Plzeň), Bejt Elend (Praha), Pražská židovská otevřená komunita - Bejt Praha (Praha), Bejt Simcha (Praha), Česká unie židovské mládeže (Praha), Židovská liberální unie (Praha), Židovské muzeum v Praze (Praha), Památník Terezín (Terezín).

3 Periodika spojená s etnokulturními menšinami žijícími v české společnosti, řazená podle etnokulturní identity vydavatele a/nebo jazyka publikace, odrážející situaci v červenci 2004 podle našeho etnografického sběru dat:

Anglická: The Prague Tribune (měsíčník), The Prague Post (týdeník).

Arménská: Nairi (měsíčník), Orer (měsíčník).

Bulharská: Roden glas (informace není dostupná), Bulhaři (měsíčník).

Italská: La Pagina (měsíčník).

Korejská: Nanumto (měsíčník).

Mad’arská: Prágai Tükör (pětkrát ročně).

Némecká: Landes-Zeitung (týdeník), Prager Volkszeitung (týdeník), Brünner Zeitung.cz (online deník).

Polská: Glos Ludu (každý druhý den), Zwrot (měsíčník), Jutrzenka (měsíčník), Ogniwo (měsíčník), Nasza Gazetka (čtrnáctideník), Kurier Praski (měsíčník), Wiarus (čtvrtletník).

Romská: (nevíme, v jaké variantě romštiny tato periodika vycházejí): Romano Kurko (čtrnáctideník), Amaro gendalos (měsíčník), Kereka - Kruh (měsíčník), Romano hangos (čtrnáctideník).

Ruská: Vesti (informace není dostupná), Russkaja Čechija (týdeník), Čechija Segodňa (měsíčník), Ogni (měsíčník), Ruske slovo (měsíčník).

Řecká: Kalimera (dvouměsíčník).

Slovenská: Listy (měsíčník), Dotyky (měsíčník), Korene (měsíčník).

Ukrajinská: Porohy (každý čtvrtý měsíc).

Vietnamská: Cay Tre (měsíčně), Vietnamcenter.cz (online deník).

Židovská: Hatikva (měsíčník v češtině), Roš chodeš (měsíčník v češtině), Maskil (měsíčník v češtině).

4 Sociální realita těchto institucí a diskurzů je relevantnějším indikátorem etnokulturní diverzity než oficiální statistiky zkoumající velikosti „etnických“ populací. V sociálních podmínkách globalizace není vhodné chápat společnost jako populaci trvale usídlených občanů. Když hovoříme o české společnosti, musíme brát v úvahu také cizince s dlouhodobým pobytem, ilegální a polo-ilegální cizince, stejně jako krátkodobé návštěvníky, jako jsou turisté. Pololegální pracovníci a krátkodobí návštěvníci mohou ,ve společnosti“ jako individua strávit pouze několik dnů nebo měsíců, nicméně jako kulturní jev a ekonomický vstup tvoří trvalou součást místních institucí a diskurzů.

5 Následující interpretace není zamýšlena jako normativní kritika výstavy a festivalu jako celku. Uvědomujeme si snahu organizátorů čelit etnocentrickým postojům tak zvané širší veřejnosti. Je zřejmé, že cítili povinnost vyjádřit svou myšlenku způsobem srozumitelným širší veřejnosti, a proto museli být citliví vůči široce sdíleným předsudkům. Avšak právě díky tomuto rysu je výstava analyticky vhodná a relevantní pro naše záměry. Slouží jako určitý druh diskurzivního mikrokosmu, který umožňuje odhalit symbolické konstrukce charakteristické rovněž pro jiné instituce a diskurzy.

6 Sexuální a jiné subkulturní formy kulturní identity jsou z tohoto diskurzu multikulturní diverzity očividně vyloučeny.

$7 \quad$ Ke konceptu poli viz Bourdieu (1998).

$8 \quad$ Ke konceptu zájmu jako illusio viz Bourdieu (1998). 
Všechny tyto př́klady byly shromážděny v České republice v letech 2002-2004, ale podle našich komparativních pozorování by snadno mohly ilustrovat obecnou situaci ve střední Evropě.

Smysl pro etnicitu je dispozice, kterou mohou určité instituce a diskurzy vyvinout v komplexní ideologické formy, jako je nacionalismus.

Analogicky, když hovoříme o etnicitě jako o určité vlastnosti kolektivit, předmět tázání by měl zahrnout praktické vědění členů dané kolektivity o etnicitě.

K tomu, jak je etnokulturní kolektivita zobrazována v praxi, viz Geertz (1973) a Eriksen (2002). Praktická kategorie etnicity umožňuje člověku přemýšlet o sobě a druhých jako o členech kvazi-přirozené kolektivity. Tato kvazi-přirozená kolektivita je obvykle artikulována v praktických diskurzech jako objekt domněle prvotních vazeb.

K rozdílu mezi koncepty diference a distinkce viz Bourdieu (1998).

Jinak je tomu v anti-modernistických narativech, kde je konstruována náhradní morální hierarchie. Nemožnost dosáhnout vrcholu mocenské hierarchie je vykompenzována pocitem mravní nadřazenosti ze strany utlačených (viz Brubaker 1992, 1996, Verdery 1996, Schulze 2003).

15 Autoři studovali procesy utváření etnokulturní identity na základě narativní analýzy autobiografických rozhovorů s Židy druhé generace, kteří v současné době žijí v České republice a v Mad’arsku (Hamar 2002a, 2002b) a kvalitativních rozhovorů zaměřených na kulturní asimilační praktiky Mad’arů a Romů žijících v České a Slovenské republice (Szaló 2002, 2004).

16 Ke konceptualizaci rozdílu mezi sebe-identitou a osobní identitou viz Goffman (1986).

17 K sociologii utváření sociální identity, obzvláště k diskurzivnímu utváření etnokulturních identit viz Szaló (2003a, 2003b) a Hamar (2003).

18 Ke strachu z ambivalence a jeho vztahu k modernitě viz Bauman (1991).

19 K expertnímu vědění a sebe-identitě viz Giddens (1991).

20 K první formulaci této otázky v sociologickém výzkumu o současných židovských identitách viz Erös et al. (1985).

21 Vycházíme z konceptu sociální inkluze, jak je formulován v textech Szaló (2003c) a Habermas (1998).

22 K relativní blízkosti různých etnických identit ve vztahu ke kulturní asimilaci a sociální inkluzi viz Alexander (1988) a Laitin (1998).

23 Ke strukturám relevance viz Berger a Luckmann (1967).

24 Tato homogenizace byla typická také pro koloniální instituce, které klasifikovaly různé neevropské etnokulturní identity za pomoci etnonym jako čínský, indický, indonéský; viz Anderson (1991). Tyto homogenizující praktiky lze vystopovat v diskurzech nadnárodní migrace.

25 Jednotlivé instituce a diskurzy se pravděpodobně liší mírou, v níž člověk může ignorovat etnokulturní identitu, kterou mu/jí druzí připisují. K logice stigmatu, informační kontroly a přecházení viz Goffman (1967).

26 Objektivizované reprezentace etnokulturní a národní identity ve znacích, na vlajkách a v rituálech není ve střední Evropě možné oddělit. Mad'arská vlajka je objektivizovanou reprezentací mad'arské národní identity ve smyslu občanství, ale také mad’arské etnokulturní identity, např́íklad v pozici menšiny. 


\section{Literatura}

Alexander, J. C. 1988. „Core Solidarity, Ethnic Outgroup, and Social Differentiation“. In: Action and Its Environment. Toward a New Synthesis. New York: Columbia University Press, s. 78-106.

Anderson, B. 1991. Imagined Communities. London: Verso.

Bauman, Z. 1991. Modernity and Ambivalence. Cambridge: Polity Press.

Berger, P. L., Luckmann, T. 1967. The Social Construction of Reality. Harmondsworth: Penguin.

Bourdieu, P. 1984. Distinction. A Social Critique of the Judgement of Taste. Cambridge, Mass.: Harvard University Press.

Bourdieu, P. 1990. The Logic of Practice. Stanford: Stanford University Press.

Bourdieu, P. 1992a. Language and Symbolic Power. Cambridge: Polity Press.

Bourdieu, P., Wacquant, L. J. D. 1992b. An Invitation to Reflexive Sociology. Chicago: The University of Chicago Press.

Bourdieu, P. 1998. Practical Reason. Stanford: Stanford University Press.

Brubaker, R. 1992. Citizenship and Nationhood in France and Germany. Cambridge, Mass.: Harvard University Press.

Brubaker, R. 1996. Nationalism Reframed. Nationhood and the National Question in the New Europe. Cambridge: Cambridge University Press.

Eriksen, T. H. 2002. Ethnicity and Nationalism. London: Pluto Press.

Erős, F., Kovács, A., Lévai, K. 1985. „Hogyan jöttem rá, hogy zsidó vagyok?“ Medvetánc, 2/3: 129-144.

Geertz, C. 1973 „The Integrative Revolution: Primordial Sentiments and Civic Politics in the New States" In: The Interpretation of Cultures. London: Fontana, s. 255-310.

Giddens, A. 1991. Modernity and Self-Identity. Self and Society in the Late Modern Age. Cambridge: Polity Press.

Goffman, E. 1986. Stigma. New York: Touchstone.

Habermas, J. 1998. The Inclusion of the Other. Cambridge, Mass.: MIT Press.

Hamar, E. 2002a. „Nalézání a vynalézání sebe v příběhu: o narativní konstrukci židovských idenit“". Biograf 27: 29-49.

Hamar, E. 2002b. „O etnicitě a konstrukci židovských identit v životních př́bězích“. In T. Sirovátka (ed.) Menšiny a marginalizované skupiny v České republice. Brno: Masarykova univerzita, s. 197-210.

Hamar, E. 2003. „Židovské identity ve světle diskursivních změn“. Sociální studia 9: 107-120.

Laitin, D. 1998. Identity in Formation. The Russian-Speaking Populations in the Near Abroad. Ithaca: Cornell University Press.

Schutz, A., Luckmann, T. 1973. The Structures of the Life-World. Evanston: Northwestern University Press.

Shulze, H. 2003. Stát a národ v Evropských dějinách. Praha: Lidové noviny.

Sirovátka, T., Hamar, E. 2001. „Romští asistenti a romští poradci: krok k řešení problémů romské komunity“. Sociální politika 27: 14-15.

Szaló, C. 2002. „Proces kulturní asimilace a konstrukce identity 'přistěhovalců’“. In T. Sirovátka (ed.) Menšiny a marginalizované skupiny v České republice. Brno: Masarykova univerzita, s. 179-196. 
Szaló, C. 2003a. „Sociologie formování sociálních identit“. In C. Szaló a I. Nosál (eds.) Mozaika v re-konstrukci. Brno: MPÚ, s. 13-36.

Szaló, C. 2003b. „Etno-nostalgie versus modernita: konstrukce sociální identity menšinového mad'arství“. In C. Szaló a I. Nosál (eds.) Mozaika v re-konstrukci. Brno: MPÚ, s. 214-234.

Szaló, C. 2003c. „Sociální inkluze a předpoklad kulturní zakotvenosti politické identity občanstvi“". Sociální studia 9: 35-50.

Szaló, C. 2004. „Svádění ke kulturní asimilaci a resistence vůči ní: o dynamice sociální inkluze mad’arské menšiny jižního Slovenska“. In T. Sirovátka (ed.) Sociální exkluze a sociální inkluze menšin a marginalizovaných skupin. Brno: Masarykova univerzita, s. 217-234.

Verdery, K. 1996. What Was Socialism and What Comes Next. Princeton: Princeton University Press.

\section{Autoři}

Csaba Szaló působí na Katedře sociologie Fakulty sociálních studií Masarykovy univerzity v Brně. Zabývá se sociologií kultury. Jeho výzkumné aktivity se zaměřují na proces kulturní asimilace a sociální konstrukce etno-národních identit. Je spolu-editorem knihy Mozaika v re-konstrukci: Formování sociálních identit v současné Střední Evropě (Brno: MPU 2003). Kontakt:szalo@fss.muni.cz

Eleonóra Hamar působí na Ústavu religionistiky Filozofické fakulty Masarykovy univerzity v Brně. Její výzkumné aktivity se zaměřují na narativní konstruování identit. Zajímá se o sociologii nacionalismu, o kulturní dějiny moderního židovství a v poslední době rovněž o teoretickou religionistiku. Kontakt: hamar@phil.muni.cz 